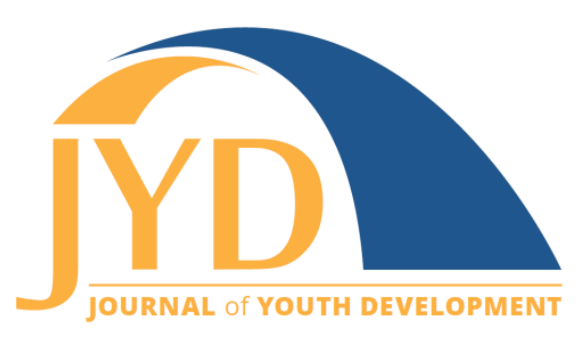

http://jyd. pitt. edu/ | Vol. 14 Issue 3 DOI 10.5195/jyd.2019.850 | ISSN 2325-4017 (online)

\title{
Social and Emotional Learning in Practice: A Resource Review
}

\author{
Allison Riley \\ Girls on the Run International \\ ariley@girlsontherun.org
}

\begin{abstract}
Youth programs are an important context for social and emotional learning (SEL). To maximize opportunities for the development of skills such as self-management, empathy, and goal setting, youth workers need resources to increase practices that support SEL. Social and Emotional Learning in Practice: A Toolkit of Practical Strategies and Resources, Second Edition is a compilation of tools, templates, and activities that youth development programs can use to (a) enhance staff knowledge of SEL, how their program supports SEL, and their own emotional intelligence; (b) establish expectations, give feedback, and integrate reflection; (c) integrate SEL into program activities; and (d) collect SEL data for improvement. The 149-page toolkit is grounded in the Ways of Being model and is also informed by youth workers and youth from a variety of organizations. This is a turnkey resource that will be useful to youth development workers with a range of goals from overhauling their approach to SEL to identifying one activity for a single day of programming. The $2^{\text {nd }}$ edition includes new icebreaker activities, an SEL Superpowers Board Game, creative data collection strategies, a reading list, and more.
\end{abstract}

Key words: social and emotional learning, Ways of Being model

\section{Introduction}

"Social and emotional learning (SEL) includes learning to be aware of and manage emotions, work well with others, and persevere when faced with challenges" (Walker, Olson, \& Herman, 2019 , p. 3). There is a growing body of research that links social and emotional skills to positive outcomes including academic achievement, workforce readiness, and improved mental health (see Durlak, Weissberg, Dymnicki, Taylor, \& Schellinger, 2011). To maximize opportunities for

(c) $\mathrm{EY}_{\mathrm{EY}}$ New articles in this journal are licensed under a Creative Commons Attribution 4.0 License. This journal is published by the University Library System, University of Pittsburgh and is cosponsored by the University of Pittsburgh Press. The Journal of Youth Development is the official peer-reviewed publication of the National Association of Extension 4-H Agents and the National AfterSchool Association. 
the development of social and emotional skills, youth programs must be intentional in their approach to SEL.

\section{Toolkit Description}

Social and Emotional Learning in Practice: A Toolkit of Practical Strategies and Resources, Second Edition, is a robust collection of tools, templates, and activities designed with and for youth program staff and young people to increase intentional SEL practices in youth programs. Although the toolkit can be used as a stand-alone resource, a 3-hour companion training, "Social and Emotional Learning in Practice," is also available.

\section{Background}

The SEL toolkit is grounded in the Ways of Being model (Blyth, Olson, \& Walker, 2017), which builds on existing SEL frameworks (e.g., CASEL, www.casel.org), but includes a focus on identity and cultural values in the SEL process. Table 1 provides an overview of the different components of the Ways of Being model.

Table 1. Ways of Being: A Model for Social \& Emotional Learning (Blyth et al., 2017)

\begin{tabular}{|l|l|}
\hline \multicolumn{2}{|l|}{ Social and Emotional Dimensions } \\
\hline Ways of Feeling & $\begin{array}{l}\text { Skills, experiences, and capacity a person uses to identify and make sense of } \\
\text { their own emotions }\end{array}$ \\
\hline Ways of Relating & $\begin{array}{l}\text { Skills youth need to understand and navigate their interactions with others } \\
\text { and develop relationships }\end{array}$ \\
\hline Ways of Doing & $\begin{array}{l}\text { Integration of Ways of Feeling and Ways of Relating, as well as other } \\
\text { cognitive skills used to approach tasks and achieve goals }\end{array}$ \\
\hline Social and Emotional Layers \\
\hline Ways I Am & $\begin{array}{l}\text { Attitudes, beliefs, and values youth have about themselves in relation to } \\
\text { their feelings, relationships, and goals }\end{array}$ \\
\hline Ways We Are Aware & Awareness of self, others, and goals \\
\hline Ways I Navigate & Process of navigating emotions, relationships, and getting things done \\
\hline
\end{tabular}




\section{Format}

The SEL Toolkit includes an introduction and is then organized around four main strategies. I provide a brief description of each here.

- Introduction: A helpful overview of the toolkit, including background and structure, and a Readiness Inventory. The Readiness Inventory helps staff focus efforts on one or several of the strategies, making integration of SEL targeted, customized, and manageable for the busy youth worker.

- Equipping Staff: Before staff can structure programs that support SEL, they need a foundation in SEL concepts and an understanding of their own SEL skills (Jones \& Bouffard, 2012). Resources in this section are designed to ground staff in the Ways of Being Model, increase awareness of their own SEL skills and cultural values, analyze their current approach to SEL, and assess their program environment.

- Creating the Learning Environment: It is important for program staff to create an environment and culture that support SEL (Herman \& Blyth, 2016). This section includes activities, tools, and templates for use with youth that help staff establish and reinforce co-created expectations, give feedback that supports development, and create space for reflection.

- Designing Impactful Learning Experiences: This section includes activities designed to promote SEL in the four Ways of Being: Ways I Am (individual and community identity), Ways of Feeling (sharing gratitude and communicating feelings), Ways of Relating (empathy and setting group norms), and Ways of Doing (developing clear goals and building consensus). Many of the activities are adapted from existing programs and organizations.

- Using Data for Improvement: Tools and templates in this section help staff create a strategy that can range from minimal work to a more extensive data collection. The ideas included here are creative and staff and youth will actually enjoy the data collection process!

Three types of resources are included within each strategy:

- Each activity includes a connection back to the Ways of Being Model, rationale, time recommendations, required materials, instructions, and extensions.

- Tools such as questionnaires and guides are designed to prompt discussion and collect feedback.

- Templates are included to supplement activities and tools and can be easily customized for any program. 


\section{Strengths and Considerations for Youth Development Professionals}

Here are a few notable strengths and considerations for professionals interested in using this resource:

- The resources include a focus on identity and cultural values, allowing youth from a variety of backgrounds to shape the SEL process through their own lens.

- Many activities and tools were designed in partnership with youth and create opportunities for youth voice and input.

- The toolkit allows for flexibility, making it easy for programs to integrate activities, tools, and templates into existing programming. The Readiness Inventory helps programs identify their specific needs, which then guides the use of resources.

- To maximize impact, programs that do not currently focus on the development of SEL skills should consider identifying outcomes of interest and an overall SEL strategy instead of selecting single activities from the toolkit to implement within their existing program. This will ensure an intentional approach.

- If a program intends to frame its approach around the Ways of Being Model, the staff may need to gain a more thorough foundation in the model than is provided in the toolkit. An issue brief is available for more information: "Ways of Being: A Model for Social \& Emotional Learning" (Blyth et al., 2017).

- The resources in the toolkit are designed for middle and high school-aged youth. Although it is indicated in the toolkit that resources can be adapted for younger age groups, programs staff should consider this aspect in their planning, as there are developmental considerations for SEL skills (Jones et al., 2017).

- The strategies and resources in the toolkit can be used simultaneously with the Youth Program Quality Assessment (Smith \& Hohmann, 2005) or other tools to support quality programming (Herman \& Blyth, 2016).

\section{Conclusion}

SEL is not an automatic byproduct of participation in youth programs. Instead, programs need to be intentionally designed to reach this end. The SEL Toolkit, Second Edition is a free, turnkey resource that would be useful to any youth development professional. 


\section{How to Obtain}

For access to the SEL Toolkit, Second Edition, visit https://extension.umn.edu/what-youthdevelopment/sel-toolkit.

\section{References}

Blyth, D., Olson, B., \& Walker, K. (2017). Ways of being: A model for social \& emotional learning (Issue brief). Retrieved from University of Minnesota Libraries Digital Conservance website: https://conservancy.umn.edu/handle/11299/195186

Durlak, J. A., Weissberg, R. P., Dymnicki, A. B., Taylor, R. D., \& Schellinger, K. B. (2011). The impact of enhancing students' social and emotional learning: A meta-analysis of school-based universal interventions. Child Development, 82(1), 405- 432. doi:10.1111/j.1467-8624.2010.01564.x

Herman, M., \& Blyth, D. (2016). The relationship between youth program quality and social \& emotional learning. Retrieved from University of Minnesota, Extension Center for Youth Development website: https://extension.umn.edu/what-youth-development/sel-toolkit

Jones, S. M., \& Bouffard, S. M. (2012). Social and emotional learning in schools: From programs to strategies. Society for Research in Child Development Social Policy Report, 26(4), 1-33. Retrieved from http://files.eric.ed.gov/fulltext/ED540203.pdf

Jones, S.M., Brush, K., Bailey, R., Brion-Meisels, G., McIntyre, J., Kahn, J., . . . Stickle, L. (2017). Navigating SEL from the inside out: Looking inside \& across 25 leading SEL programs: A practical resource for schools and OST providers (Elementary School Focus). New York, NY: The Wallace Foundation.

Smith, C., \& Hohmann, C. (2005). Full findings from the Youth PQA validation study. Ypsilanti, MI: High/Scope Educational Research Foundation.

Walker, K., Olson, B., \& Herman, M. (2019). Social and emotional learning in practice: $A$ toolkit of practical strategies and resources ( $2^{\text {nd }}$ ed.). St. Paul: University of Minnesota Extension. 